\title{
NEW ZEALAND'S FIRST CHIEF JUSTICE: THE RULE OF LAW AND THE TREATY
}

Peter McKenzie $Q C^{*}$

This article builds on the contribution George Barton made on the life of Sir William Martin, New Zealand's first Chief Justice, in the Dictionary of New Zealand Biography. That entry indicates the keen interest George Barton had in the culture of the law including the history of the legal profession. This article seeks to show that New Zealand's first Chief Justice was a figure of major significance in New Zealand's early history, not only because of the way he pioneered the establishment of the superior courts in New Zealand and sought to adapt English procedures to the needs of the new colony, but more significantly in the way he used his legal and linguistic skills to encourage Māori towards a society based on the rule of law, and used those skills to provide New Zealand's early government with an understanding of the Treaty of Waitangi. His forceful and eloquent arguments on the rights confirmed to Māori under the Treaty, although unpopular and resented by many at the time, have become a powerful resource for Treaty historians today, and deserve greater attention by New Zealand's professional historians.

\section{GEORGE BARTON AND LEGAL HISTORY}

The subject of this essay was awakened for the author by the contribution made by George Barton QC to the Dictionary of New Zealand Biography on the life of Sir William Martin, New Zealand's first Chief Justice. ${ }^{1}$ This was an article that arose from George Barton's keen interest in the history of the law and those who had held judicial office.

George Barton had a broad and almost encyclopaedic approach to the law. He was fascinated by the culture of law and the way in which legal institutions have developed. For this reason it was

* Peter McKenzie QC was from 1966 to 1976 a colleague of Dr Barton's on the Law Faculty of Victoria University of Wellington. During this period from 1969 to 1975 he shared barristers' chambers in Lambton Quay, Wellington with Dr Barton. The author is indebted to Dr Bryan Gilling for reading this article in draft and providing many helpful comments. The author, however, takes responsibility for any views, historical or otherwise, expressed in this article.

1 GP Barton "Martin, William" Te Ara (New Zealand Dictionary of Biography) < www.teara.govt.nz>. 
particularly fitting that he was appointed Queen's Counsel in $1990 .^{2}$ For him to 'take silk' was far more than a matter of peer recognition or seniority within the bar. To become a Queen's Counsel was for George Barton to become part of a long and living tradition going back to the days of Queen Elizabeth I and to join a rank of practitioners, each with their own story. These were lawyers who competed with the sergeants-at-law for pre-eminence in the practice of law and who have maintained a tradition of independence that was to be the mark of advocacy at the English bar.

Those who learned procedure from George Barton had it instilled into them that the strength of the substantive law was born out of procedure. ${ }^{3}$ It is not surprising, therefore, to find that George Barton's absorbing interest and love for the history of the law found expression in a series of cases where he resorted to the armoury of earlier legal procedure in order to find a remedy to deal with the current novel situation.

Few New Zealand lawyers would have heard of the ancient writ of ne exeat regno which George Barton pleaded before Hardie Boys J in the Supreme Court (now the High Court) at Wellington, seeking an order in terms of this writ, to restrain the All Black rugby team from leaving the country to tour South Africa. ${ }^{4}$ Hardie Boys $\mathrm{J}$ was not prepared to extend the scope of the writ beyond providing a process available to the Crown in matters of State and held that the writ was not available to a private citizen. Dr Barton remained unrepentant, stating some years later, in the scrupulously correct manner typical of him, "I have always thought that the decision was wrong; but that is not relevant now - if it ever was". ${ }^{5}$

George Barton's most celebrated application of legal history in the law courts was his legal joust with Sir Robert Muldoon. ${ }^{6}$ This case concerned Muldoon's action, soon after being elected as Prime Minister in 1975, in issuing a press release purporting to abolish the superannuation scheme established by the previous Government under the New Zealand Superannuation Scheme Act 1974. No law had at that time been passed to abolish the scheme, but that did not present an obstacle to the

2 The reason why that appointment was not made much earlier has a story of its own which I shall need to leave others to tell.

3 Glanville Williams (ed) Salmond on Jurisprudence (11th ed, Sweet \& Maxwell, London, 1957) at 503-505.

4 Parsons v Burk [1971] NZLR 244 (SC Wellington). Roy Parsons of the well-known Wellington bookshop lent his name to this proceeding.

5 The author is indebted for this information to Gary Turkington, a Wellington barrister who provided the author with a letter he had received from George Barton dated 21 June 2007 where George Barton recounts, as only he could do, his quest for the only known textbook on the writ, John Beames A Brief View of the Writ Ne Exeat Regno: With practical remarks upon it as an equitable process (W Reed, London, 1812). To his surprise he discovered a copy of the book in the possession of a Turkish law professor, so knew it existed, and was able with the help of Gerry Bowden, a former law faculty colleague from the United States, to locate a copy held by booksellers in Germany.

$6 \quad$ Fitzgerald $v$ Muldoon [1976] 2 NZLR 615 (SC Wellington). 
Prime Minister who declared that the abolition of the superannuation scheme was to have immediate effect. In proceedings brought to challenge the validity of the Prime Minister's action, Wild CJ upheld George Barton's argument that the Prime Minister's action violated art 1 of the Bill of Rights 1689 which provided, "that the pretended power of suspending of laws or the execution of laws by regal authority without consent of Parliament is illegal". The case has been cited on numerous occasions since. ${ }^{7}$

George Barton was regarded by those who knew him as an extraordinary resource for little-used legal remedies. He retained these in his mental encyclopaedia for use when the appropriate occasion required. The author recalls such an instance when over coffee, the author related to him an unusual set of circumstances on which the author had been called to advise in a Pacific Island jurisdiction. A lawyer in this island had been instructed to institute legal proceedings challenging the constitutional validity of a Government appointed after a coup on the island. An initial application to restrain certain executive action pending the determination of the constitutional validity of that action was immediately appealed by the Attorney-General appointed under the coup. That application had come before a pre-coup judge but the executive managed to ensure that the appeal and all subsequent steps were brought before post-coup judges. The lawyer had the temerity to challenge a succession of appeal court judges who dealt with his application claiming that these judges should recuse themselves. Each such attempt was summarily rejected with penal personal costs being awarded against the lawyer. In frustration I told Dr Barton that the procedure for recusal at common law was a very deficient one as it placed in the hands of the judge, who it was sought to have removed, the making of the decision whether or not he or she would stand aside. George Barton had an immediate response, "Oh, what you need is a writ or application for coram non judice [before one who is not a judge]." Sure enough, subsequent researches revealed that there was indeed such a remedy where application can be made to the court challenging the jurisdiction of the court on the ground that, literally, "the court is without a proper judge or without a legal venue". Although not used recently in England, there were several instances where a procedure of this kind had been used in the United States. It had the advantage, in the circumstances of the case with which the author was concerned, that an application on this ground would necessarily have to be heard by a judicial officer other than the officer who it was claimed was unqualified to hear the proceeding. However, as often happens in such cases, events moved beyond the point where the remedy suggested by Dr Barton could be tested.

George Barton's interest in legal history led him to commence teaching legal history at the law school at Victoria University of Wellington. The course was introduced in 1968 as one of the optional courses offered for the LLB(Hons) programme when the undergraduate law degree was restructured that year. The course description in that and subsequent years was brief: "Aspects of legal history in New Zealand and Great Britain". George Barton's interest was in the law as a living

7 See for example Unitec Institute of Technology v Attorney-General [2006] 1 NZLR 65 (HC). 
instrument where its past could illuminate and assist in providing a legal remedy today. It is not surprising, therefore, that the main focus of the legal history course was on the development of the common law and the institutional framework of the law. The prescribed texts first named in 1973 were indicative of this. ${ }^{8}$ The major interest of New Zealand legal historians today, centred on the impact of the Treaty of Waitangi, was at this time still in the future.

\section{WILLIAM MARTIN: NEW ZEALAND'S FIRST CHIEF JUSTICE}

As mentioned at the outset of this article one of the excursions into New Zealand legal history made by George Barton was his contribution to the Dictionary of New Zealand Biography on the life of New Zealand's first Chief Justice, Sir William Martin. It is this subject that the present article seeks to develop.

\section{A Sir William Martin}

George Barton's article on Martin recognised his significance in New Zealand's early history, stating that "he enjoyed the enviable distinction of being universally respected by all parties and all races" but Martin has, with the exception of Claudia Orange ${ }^{9}$ and Keith Sinclair, ${ }^{10}$ been a neglected figure by New Zealand's leading contemporary historians. ${ }^{11}$ This neglect has been partially redressed by the work of the Treaty historians in submissions and reports generated by cases before the Waitangi Tribunal and there is a growing recognition by them that Martin had a significant role in race relations. ${ }^{12}$ His stand on issues relating to Māori, although largely repudiated at the time, is today seen as wise and temperate and one that could have spared New Zealand the worst features of the Land Wars and the confiscations that followed.

It is surprising that Martin has been so neglected by contemporary historians when, as Dr Barton indicated in his article, the historical evidence shows that he was held in the highest respect by all sections of New Zealand society, including those who were hostile to the stance he took on Māori issues. Henry Sewell states that Martin was "facile princeps [easily first] in the colony"13 and "was

8 JH Baker An Introduction to English Legal History (Butterworth and Co, Toronto, 1971) and SFC Milsom Historical Foundations of the Common Law (Butterworths, London, 1969).

9 Claudia Orange The Treaty of Waitangi (Allen \& Unwin, Wellington, 1987).

10 Keith Sinclair The Origins of the Maori Wars (2nd ed, NZ Universities Press, Wellington, 1961).

11 John Stenhouse "Selwyn Through Settler Eyes" in Allan Davidson (ed) A Controversial Churchman (Bridget Williams Books, Wellington, 2011) 88 at 102-103.

12 A significant earlier treatment of this subject is MW Hancock "Sir William Martin and the Maori people" (MA thesis, Victoria University of Wellington, 1950).

13 W David McIntyre (ed) The Journal of Henry Sewell (Whitcoulls Publishers, Christchurch, 1980) vol 1 at 40. 
respected by all sections of society". ${ }^{14}$ He held Martin in such esteem as to record, "There is only one man here to consult with confidence about any thing - the Chief Justice, who seems to have everybody's good opinion" and described his conversation as "sensible, practical and right-minded" in contrast to the Attorney-General William Swainson who, although intelligent, suffered from "feebleness of character". ${ }^{15}$ Busby, who strongly opposed Martin's views on the nature of Māori land tenure, professed to put forward his opposing views with some diffidence because "it may savour of presumption" to "attempt to controvert the opinions and reasonings of a person so eminent as Sir William Martin". ${ }^{16}$

Martin was viewed with some caution by the missionaries who, as low churchmen, were suspicious of his middle to high-church tendencies and close association with Bishop Selwyn. Despite that reserve he was held in respect by them. ${ }^{17}$ When Sir William and Lady Martin left New Zealand to return to England in 1874 the Southern Cross newspaper paid tribute by stating that "New Zealand lost one of its brightest ornaments" and referred to Martin's devotion to the welfare of both races. 18

\section{B Brief biography of Martin}

The background facts relating to New Zealand's first Chief Justice are well known. He was born in Birmingham, England in 1807, educated at King Edward VI Grammar School, Birmingham and

14 Ibid at 73

15 Ibid vol 2 at 40-41. Sewell visited Martin to say goodbye on Martin's return to England in 1857 and commented, at 79, that it was "impossible not to like him greatly" and hoped he would be succeeded by someone of his distinction stating "a really good Chief Justice would be a sort of new soul to the colony".

16 James Busby Remarks upon a pamphlet entitled The Taranaki Question by Sir William Martin DCL late Chief Justice of New Zealand (Phillip Kunst, Auckland, 1860) at 3.

17 William Williams regarded Martin as "a most agreeable man, and one who has much at heart the well being of the natives". Jane Williams, in typically Victorian evangelical prose, described Martin as "a very pleasant man with a good deal of common sense but wanting a right sense of the one thing needful" (in other words an evangelical view of the gospel): Frances Porter (ed) The Turanga Journals: 1840-1850 (Price Milburn, Wellington, 1974) at 232-233 (letters dated respectively 28 November 1842 and 29 November 1842). Octavius Hadfield as early as 1842 described Martin along with Selwyn "as the two most talented men in New Zealand ... They are both attached in a most extraordinary manner to the natives and seem determined to defend the natives interests": letter from Octavius Hadfield to his family (19 November 1842) reproduced in Barbara Macmorran Octavius Hadfield (David F Jones, Wellington, 1969) at 178. In a letter to his sister Octavia dated 13 November 1843, cited by Macmorran at 181, Hadfield refers to Martin's "great interest in the [Māori] language and in the natives of this country". George Clarke, Chief Protector of Aborigines (1840-1846) and a missionary wrote that Martin was, "so far a master of the Maori language, and took so lively an interest in the welfare of the Aborigines as permanently to win their confidence and esteem": Pamphlet in answer to Mr James Busby's "On the Taranaki Question and the Treaty of Waitangi" (1861) reprinted by AF McDonnell, Auckland, 1923 at 2.

18 "Proposed Address to Sir William Martin" Daily Southern Cross (New Zealand, 9 April 1874) at 3. 
at St John's College Cambridge. ${ }^{19}$ Martin showed particular facility in languages and studied for the classical tripos at Cambridge. He was elected a fellow and tutor of St John's and in 1832 entered Lincoln's Inn to study for the Bar, being called to the Bar in 1836. He worked in equity chambers specialising in drafting and equity conveyancing but did not practice in the courts. In January 1841 he was appointed the first Chief Justice of New Zealand. The circumstances in which he was selected for this position remain obscure but there can be little doubt that his close friendship with George Augustus Selwyn, who was appointed first bishop in the Anglican Church in New Zealand in the same year that Martin was appointed Chief Justice, was an influencing factor. Martin and Selwyn had been students together at St John's. Before taking up his new position, Martin was married to Mary Ann Parker who, during her time in New Zealand, was a significant figure in her own right, establishing one of New Zealand's first hospitals serving the Māori people and taking a lively interest in their welfare. ${ }^{20}$

Martin arrived in New Zealand on 9 August 1841, travelling to this country on the Tyne with William Swainson who was to be the new Attorney-General and Thomas Outhwaite the Registrar of the Supreme Court. It was a productive partnership. George Barton in his lectures on civil procedure made the point to his students that the Ordinances setting up the first New Zealand Supreme Court and providing for its jurisdiction and procedure were settled on board the Tyne on the way out to New Zealand.

Martin was for several months the only Supreme Court judge in New Zealand and sat in both Auckland and Wellington. ${ }^{21}$ In February 1844 Henry Chapman assumed judicial office in Wellington and took responsibility for the lower part of the North Island and the South Island. Martin and Chapman were commissioned to produce rules for the practice and procedure of the Supreme Court which were issued in 1857. It was a significant project and forms the basis of later Codes of Civil Procedure in New Zealand. The new rules sought to promote simpler and less technical pleadings and, to that end, abolished the distinction in pleading between actions in law and suits in equity, prohibited the use of fictions in any pleading, and required the statement of facts in any pleading to be in "ordinary and perspicuous" language without any repetition. ${ }^{22}$

The approach of Martin and his wife to life in New Zealand was deeply influenced by their devout Christian faith. Martin gave significant time to assisting Selwyn in developing St John's

19 Guy Lennard Sir William Martin (Whitcombe and Tombs, Christchurch, 1961) at 2-3. St Johns was also the College at Cambridge at which George Barton studied. He remained a loyal supporter of St Johns and this link with his old College no doubt appealed to him.

20 Mary Martin gave her account of her early years in New Zealand in Our Maories (SPCK, London, 1884) facsimile ed reprinted by Wilson \& Horton, Auckland, 1970. Her story is winningly told by Arthur Meek in a dramatic production which this author hopes will be presented again, On the Upside Down of the World.

21 Nelson was served from Wellington, and Christchurch and Dunedin had not been settled at that time.

22 Peter Spiller The Chapman Legal Family (Victoria University Press, Wellington, 1992) at 38-40. 
College at Auckland and gave lectures at the College. He worked with Selwyn on a constitution for the Anglican Church in New Zealand.

His contemporaries viewed Martin as a modest and retiring person due in part to his conscientious belief that the holder of judicial office should be a person apart from the gossip of a close colonial society. For this reason he purchased property for his home some distance from the settlement at Auckland, a view also adopted by Chapman on his arrival in Wellington when he chose to live at Karori. ${ }^{23}$ It may be for this reason that, although respected, Martin did not endear himself to the legal profession as did his more convivial successor, Arney CJ. ${ }^{24}$

Martin and his wife had a deep respect for Māori and regarded good and just relationships with Māori as central to any settlement by Europeans in this country. Martin treated seriously the rights of Māori as British subjects under art 3 of the Treaty of Waitangi and regarded it as important to the future of the country that Māori understood their rights and the protections available under the law. In this respect, Martin saw the law as having a central role in bringing stability to a new country. If both communities, Māori and settler, could live together under the rule of law a strong and unified society would emerge.

In 1856, after 15 years' service as Chief Justice, Martin's health broke down. He was not a physically strong person and the rigours of life in early New Zealand had taken their toll. ${ }^{25}$ He was given leave to recuperate in Italy but remained unwell and on 12 June 1857 while still outside the country he formally tendered his resignation. The Martins returned to New Zealand in December 1858 after three years' absence and continued to live here until 1874 when they returned to England where Martin died at Torquay in 1880. During this further 16 years in New Zealand, Martin was active in church affairs and in St John's College but took up no further public office. However, during the period prior to and following the Land Wars he was a vigorous critic of the policy and actions of the colonial government.

Martin's active role in promoting the role of the law in early New Zealand is seen particularly in the following areas and the discussion of these areas forms the central part of this article:

23 Ibid at 35.

24 Robin Cooke (ed) Portrait of a Profession: the centennial book of the New Zealand Law Society (AH \& AW Reed, Wellington, 1969) at 39-40.

25 Although Martin had a much less robust constitution than the athletic Selwyn, this did not deter him from accompanying Selwyn in 1842 on an arduous trek from Wellington through the Manawatu to Hawke’s Bay, across the ranges to the Bay of Plenty and Auckland to become acquainted personally with the territory and populace for which they had respectively become responsible. A feature of his period as Chief Justice was, as George Barton noted in his biographical entry, long overland journeys to New Plymouth, Wanganui, and Taupo to meet with Justice Chapman. 
(1) using the judicial role to promote respect for the law and advocate the legal process as the means of providing quick and effective justice;

(2) developing resources in the Māori language to promote understanding of the legal process;

(3) Martin's understanding of the Treaty of Waitangi;

(4) Martin's position on Māori title to land and Māori land rights; and

(5) the land confiscations and the rule of law.

\section{USING THE JUDICIAL ROLE TO PROMOTE RESPECT FOR THE LAW}

At the time he accepted appointment as New Zealand's first judge, Martin doubtless realised the challenging nature of the role for the first law officer to be appointed in the new colony. In 1842 when Martin began his judicial duties the country had little more than 11,000 European settlers living in isolated pockets of the country with the main areas of settlement being the Bay of Islands, Auckland, Wellington and Nelson with smaller centres at New Plymouth and Wanganui. ${ }^{26}$ There was a larger Māori population of over 100,000 scattered across both islands but with the main centres of population being in the north.

It was axiomatic for Martin and those who appointed him that British settlers in New Zealand would be governed by English law and legal institutions patterned on the English model. Colonists from Britain regarded it as their birthright as British subjects to take with them the English jury system, the general framework of English common law and associated statutes and the rights and freedoms deriving from the English constitutional system hammered out at the time of the Stuarts. ${ }^{27}$ A major challenge for the new Chief Justice was to work with what would be an essentially English framework of law and institutions and adapt these to administering justice in a new country with a substantial population of indigenous people. The indigenous people had already acquired a widespread degree of literacy (in Māori) with possibly a greater level of literacy than the European population. ${ }^{28}$

New Zealand had a reputation for lawlessness. One of the reasons for promoting the Treaty was the ineffective attempts to hold out-of-control British subjects accountable under the law, including

26 Wellington had a significantly greater population than Auckland and this led to vigorous complaints from the Wellington lawyers, championed by HS Chapman before he was appointed a Supreme Court judge, that Auckland was the wrong place to site the Supreme Court and a judge should be appointed to serve Wellington and Nelson: HS Chapman The New Zealand Portfolio (Smith Elder \& Co, London, 1843) republished by the Hocken Library in 1969.

27 BH McPherson The Reception of English Law Abroad (Supreme Court of Queensland Library, Brisbane, 2007) at ch 6, specifically at 205-206 and 227-231.

28 James Belich Making Peoples (Allen Lane, Auckland, 1996) at 224. 
many ex-convicts who had settled in New Zealand. There was also a great need to bring stability to a country that had been devastated by the musket wars and where the exposure to a new and different culture was breaking down traditional patterns of society. As stated in the Preamble to the Treaty:

Her Majesty being desirous to establish a settled form of Civil Government with a view to avert the evil consequences which must result from the absence of necessary laws and institutions, alike to the Native population as to Her Majesty's subjects.

The new Chief Justice was assisted by the fact that many Māori welcomed the introduction of a system that could bring more settled conditions to the country. James Belich in his social history refers to the welcome given in inland districts to European magistrates and officials who came as mediators, ambassadors and settlers, citing Alan Ward that "the coming of 'the law' was hailed as enthusiastically as the coming of the gospel". ${ }^{29}$ Martin later referred to the "the widespread movement amongst the Natives towards some regular system of law and organisation for themselves". 30

Martin considered that in the early years of the colony the court had a pivotal role in demonstrating that there were real benefits in administering justice in an orderly and public way by an impartial judge and a jury in a society governed by the rule of law, over the self-help forms of justice otherwise available to a frontier society. His reflections on the role of the law in his years as Chief Justice are given in observations that he put before Parliament in 1864 in which he commented on the task faced by the new Government in $1840:^{31}$

It was plain that many years must elapse before our colonisation should extend over the whole country.

It was hoped that by good management during those years the Natives would gradually learn the meaning of the Queen's sovereignty by practical experience of the benefits flowing to themselves from it, and so would come to an intelligent appreciation and acceptance of the new system of things. The contrast seen and felt between the effects of lawlessness and law; the manifest benefit of an order of things which should allow the Natives to accumulate property and enjoy the fruits of their labour, would (it was hoped) wean them gradually from their own habits into ours, until a more complete establishment of our system should become practicable.

Martin's approach to race relations was undoubtedly one that favoured assimilation. He was a mid-Victorian with the confidence of his generation that he was an agent in the bringing of the benefits of European civilisation to other parts of the world. But for Martin this process was to be

29 Ibid; see also Alan Ward A Show of Justice (Australian National University Press, Canberra, 1974) at 136.

30 William Martin "Further Papers relative to The Taranaki Question" [1861] I AJHR E2 at 21.

31 William Martin "Observations on the Proposal to take Native Lands under an Act of the Assembly" [1864] I AJHR E2c at 6 ("Confiscation of Native Lands"). 
achieved peaceably and by free consent on the part of Māori. They were to be free to adapt to the benefits that he saw arising for them from 'the new system of things' but were also free to continue under their customary usages which would continue to have the protection of the law. ${ }^{32}$ That freedom did not extend to the criminal law which in its essentials he saw as applying to both races. This law could, however, only be applied with the willing cooperation of Māori and particularly their chiefs. He saw his role as being one where he was to ensure that the fairness and openness of the legal process would commend itself to Māori. The Chief Justice applied this view of his role in the way he administered justice. His first trial of any significance was one that provided him with just such a platform. ${ }^{33}$ Maketu was a Māori charged with the murder of European settlers and a half-caste child. As George Barton noted in his article, ${ }^{34}$ the Chief Justice after hearing argument from counsel assigned to represent the accused held that although Maketu may have been unaware of English law, he was as a subject of the Crown governed by English law and the Court had jurisdiction to try him. An application by Maketu's counsel that he be tried before a jury of equal numbers of Pakeha and Māori jurors was also dismissed on the ground that as he was not an alien he was not entitled to be tried otherwise than by an ordinary jury. ${ }^{35}$ The whole proceedings were interpreted into the Māori language as much for the benefit of the accused as the many Māori onlookers. Maketu, after a trial, in the course of which witnesses were called and cross-examined, was found guilty and when pronouncing the death sentence Martin chose to address the accused in terms he believed the accused (and the surrounding crowd) would understand, "The death sentence being discussed by this Judges Panel is one that has been agreed to by your own people; they have also said 'old man go and be with your ancestors"'. ${ }^{36}$ Less than a week later Maketu was executed on the prison gallows next to the courthouse. Martin describes the impact in these words: ${ }^{37}$

And certainly the spectacle of our criminal trials did produce a great effect on the minds of all the natives who witnessed them, or who heard the story of them as it was carried throughout the land. Tardy they thought our procedure to be, and even cruel; but men accustomed to the indiscriminate vengeance of tribe against tribe were struck with awe at the sight of a system, which slowly yet surely, tracked out

32 Ibid at 7. Martin here treated the position in New Zealand following the assumption of sovereignty under the Treaty as being akin "to our Indian possessions" where divers races of men under divers systems of law dwell together under one Sovereign. This issue is discussed further later in this article.

$33 R v$ Maketu SC Auckland, 1 March 1842 available at <www.victoria.ac.nz/law/nzlostcases/>

34 GP Barton "Martin, William", above n 1. See also Guy Lennard Sir William Martin: the life of the first Chief Justice of New Zealand, above n 19 at 10-21.

35 The Ordinance on Juries issued by the Governor in Council placed a property qualification on eligibility for jury service that, in practice, would have disqualified almost all Māori at that time. This qualification was removed in the interests of obtaining a mixed jury by the Juries Ordinance 1844. See fn 42 below.

$36 \quad R v$ Maketu, above n 33, at 29.

37 "Confiscation of Native Lands", above n 31, at 6. 
the single shedder of blood, and smote him alone. The execution of Maketu was approved everywhere;

even in the north among his own people, it was not resented.

It is likely that Martin arranged that the next case called before him was the prosecution of a European for criminal assault on a Māori male. ${ }^{38}$ The court was crowded to excess, the considerable interest in the proceedings being on account of the well known respectability of the defendant who was a Pakeha sea captain. The defendant was sentenced by Martin to two years' hard labour. In the first case brought by the Crown Prosecutor against a Māori, ${ }^{39}$ Martin took care to ensure that the proceedings were fully explained by the interpreter in Māori. ${ }^{40}$ The defendant was charged with stealing a double-barrelled shot gun and two baskets of potatoes. The court report indicates that Martin CJ was anxious that the interpreter should take care that the prisoner: ${ }^{41}$

... should not only hear distinctly but, if possible, understand perfectly the charge which so materially affected his future life and on which he was to be tried not by a jury of his own countrymen but by Englishmen.

The Judge then, through the interpreter, explained the defendant's right to challenge up to six members of the jury and assigned a barrister to represent the defendant. The evidence showed that the defendant was part owner of the gun and he was acquitted by the jury. Martin no doubt expected that, with his careful explanation of the various steps in the proceeding, Māori present would appreciate the fairness of the process.

The difficulties which the judge encountered in applying an alien system of law, and the serious consequences in this not being seen to be manifestly fair, is well illustrated by a trial in Wellington in March 1843. ${ }^{42}$ A rough Pakeha settler at Cloudy Bay, Richard (Dick) Cook, was accused of the murder of Kuika, the wife of another settler and her child. Kuika was the daughter of a high-ranking chief and the case was of great concern to local Māori. It was with some difficulty that the missionary in Marlborough, Samuel Ironside, persuaded Māori that Cook should be handed over to the Crown Prosecutor at Wellington to be dealt with by Pakeha justice. The Crown Prosecutor mishandled the trial and was taken by surprise when the evidence of his only witness, Cook's wife, was challenged by Cook's counsel as being inadmissible. Martin CJ had no option but to direct that her testimony could not be given. There was strong circumstantial evidence pointing to Cook, in the

$38 R \vee$ Francis Leethart (Captain) SC Auckland, 2 March 1942 available at <www.victoria.ac.nz/law/ nzlostcases/>.

$39 R v$ Poti SC Auckland, 7 October 1842 available at <www.vuw.ac.nz/law/nzlostcases>. The Maketu case was prosecuted by the Attorney-General.

40 The interpreter was George Clarke, a former missionary who was Protector of Aborigines.

$41 \quad R v$ Poti, above n 39.

42 CA McDonald Pages From The Past (H Duckworth, Blenheim, 1933) at 157-161. 
form of blood-stained clothes and the murder weapon, but it would appear that as the Crown had no other witnesses that evidence could not be given and the all-Pakeha jury, on the Chief Justice's direction, returned a verdict of not guilty. To compound Martin CJ's problems, attempts to bring Māori witnesses against Cook over from Cloudy Bay were thwarted, as the Government would not meet the costs of bringing them, leading to a public protest in court by the Judge and prosecutor. ${ }^{43}$

The outcome of this trial provoked a strong reaction from the relatives of Kuika. Samuel Ironside wrote to the Chief Justice expressing his concern at the inadequate evidence presented by the prosecution and the desirability of having a mixed jury in such cases. He received what Ironside described as a "courteous" reply stating that the rule as to inadmissiblity of a wife's evidence against her husband was "not less wise than it was inflexible" and that the use of mixed juries in important criminal cases was "under consideration". ${ }^{44}$ The failure of Pakeha justice on this occasion clearly rankled with Māori in Marlborough. Following the Wairau incident three months later the Ngāti Toa chief, Rangihaeata, raised in justification (among other matters) the accusation that "they did not punish the murderer of Kuika". ${ }^{45}$ The unexplained killing of four Pakeha settlers in the Wairau valley prior to the Wairau incident may have been a revenge killing for the lack of justice in relation to Cook. ${ }^{46}$

Notwithstanding the small population of the country at this time the Supreme Court was not lacking in work. The New Zealand Lost Cases Project records that in the Supreme Court's first year 31 cases were heard, and Martin during his 14 years as Chief Justice heard a total of 252 cases. ${ }^{47}$

43 The New Zealand Colonist and Port Nicholson Advertiser (Wellington, 18 April 1843) at 2. Strangely the newspaper did not report the trial, even though reports of court proceedings formed a major part of its copy. The only mention of the Cook case is the report of the criticism of the Government's refusal to meet the costs of bringing Māori witnesses to Wellington. It may be for this reason that the New Zealand Lost Cases project has not included a report of this case.

44 The law relating to eligibility for jury service was changed in the Temporary Jury Provision Ordinance 1844 7 Vict 2 which provided for mixed juries. Section 1 provided "Any aboriginal native of New Zealand whose capability may be certified under certain regulations to be from time to time issued by the Governor and Executive Council shall be held duly qualified and liable to serve as a juror on a mixed jury for the trial of any case, civil or criminal, in which the property or person of any aboriginal native of New Zealand may be affected."

45 CA McDonald Pages From The Past, above n 42, at 175. I am indebted to Professor Richard Boast for some of the details of this story which were referred to by him in a paper prepared for Ngāti Toa, derived from George Clarke Jnr's reminiscences, Notes on Early Life in New Zealand (J Walch, Hobart, 1903). George Clarke Jnr was interpreter in this case and expressed serious disquiet about the miscarriage of justice and its negative impact on Māori.

46 TL Buick Old Marlborough (Hart \& Keeling, Palmerston North, 1900) reprinted by Capper Press, Christchurch, 1976 at 245-249.

47 These figures represent only defended cases heard in court and reported in some way. That they represent only a fraction of the Court's work is apparent from a report in The New Zealand Colonist and Port Nicholson Advertiser of 10 March 1843 that 29 civil cases were listed for Martin CJ to deal with in the 
The nature of the litigation dealt with by Martin and Chapman which is recorded in the New Zealand Lost Cases Project provides a fascinating vignette of New Zealand colonial life but there is no space in this article to expand on this topic.

\section{DEVELOPING RESOURCES IN THE MÄORI LANGUAGE TO PROMOTE UNDERSTANDING OF THE LAW}

Martin's belief that the law had a pivotal role in providing stability and progress in the new colony naturally led him, with his facility in the Māori language, to develop resources to aid Māori in understanding the nature of the legal process and the benefits the rule of law could bring to them. Within three years of commencing his duties as Chief Justice, Martin had produced a booklet, Ko Nga Tikanga a te Pakeha, ${ }^{48}$ in Māori and English to educate Māori about their legal rights and which described the way in which the courts operate and how a trial before the court is conducted.

Martin's booklet was published as a serial in Te Karene Maori (The Maori Messenger) in March 1856 and subsequent months. ${ }^{49}$ Guidance is given in the booklet about the way a trial is conducted. An explanation is provided, with examples, of the nature of the jury system and the role of the judge. One example is taken from a case where two Pakeha were charged with breaking into $\mathrm{Mr}$ Nathan's store at Auckland and stealing two guns. Martin describes and explains in some detail the way in which the case was conducted.

In another article Martin discusses a case at Anaura Bay on the East Coast where the community had refused to hand over a local Māori, Perenaha Perehia, to magistrates sent over from Tauranga and compares this with the case of Charles Marsden who killed a Māori woman and his life was required under the Queen's law as a penalty. In these ways he strove to assure Māori that justice would be administered in an even-handed way and the one law would apply with fairness to both Pakeha and Māori.

Martin had attempted to provide an understanding of the way the law applied that Māori with no background in the working of the English-based legal system would find helpful. The next stage in such a project would have been the provision of a description in basic language of the laws that particularly affected Māori such as the common crimes, a description of the principal torts affecting Māori and a simple statement of the law relating to contract and borrower and lender. The Colonial

March 1843 sittings at Wellington. Those involved in researching New Zealand's early legal history are greatly indebted to the Lost Cases Project conducted by Victoria University of Wellington Law School which has compiled from contemporary sources a record of Supreme Court and Court of Appeal cases heard during the period 1842 to 1869.

48 William Martin "Ko Nga Tikanga a te Pakeha" (1845) New Zealand Electronic Text Centre $<$ www.nzetc.org>. The author is indebted to assistance from Māmari Stephens of the Law Faculty at Victoria for information that led to gaining access to this publication.

49 The Maori Messenger (1856) < sadl.uleth.ca >. 
Government attempted to do this in a publication issued by Governor Gore Browne in $1858 .{ }^{50}$ It would seem that Martin was not consulted on the preparation of this volume and he was clearly not impressed by it. It was a tabulation in English with a transliteration on the opposite page into Māori, of a prescriptive statement of English laws dealing with a wide range of criminal offences and civil injuries. A section of the volume attempted in somewhat less technical language to provide an explanation of the statement of the law. An analogy would be a literal translation into Māori, using a large number of English technical terms, of the volumes on the criminal law and torts in Halsbury's Laws of England. Martin criticised the publication in these terms: ${ }^{51}$

This book no doubt had a considerable effect in stimulating the movement [for establishing procedures to support law and order among Maori themselves] but it failed to indicate to the Maories the course which it was necessary for them pursue. Some Maori principles of law were clearly explained, but too much of the artificial structure and technical language of our law was retained. Taken as a whole the book was far too multifarious and complicated. Much of it was occupied with matters which must always be confined to the English courts. There was little or nothing adapted to the very peculiar needs and difficulties of the Maories at that time.

Martin went on to criticise the lack of progress made in implementing legislation that had been enacted to appoint a Resident Magistrate in every native district and provide for the introduction of regulations, which were to have the general assent of the native population, which would set out matters to be dealt with by Magistrates in Native Circuit courts. Martin deplored the Government's neglect in doing anything to "guide the Native mind towards law and order", 52 and that the Government had largely limited its relations to Māori to the role of a land purchaser. "In many parts of the country there was no indication of the Queens' sovereignty; the Natives scarcely knew the Government except as a purchaser of land." 53

50 Ko Nga Ture O Ingarani; He Mea Whakahau Iho - The Laws of England compiled and translated into The Maori Language (National Secretariat Office, Auckland, 1858). The author is indebted to Professor Anthony Angelo for providing access to a volume in his personal collection.

51 William Martin "Further Papers relative to the Taranaki Question", above n 30, at 25.

52 Ibid.

53 Ibid at 26. It was a major concern of Māori leaders such as Wiremu Tamihana that the Government was not doing more to develop respect for the law in the Māori interior, and this was one factor that led Tamihana to take a leading part in the King Movement: Evelyn Stokes Wiremu Tamihana: rangatira (Huia Publishers, Wellington, 2002) at 151 and 179-180. Martin refers to this in William Martin "Further Papers relative to the Taranaki Question", above n 30, at 22. There had been a significant shift in policy in this respect under Governor Grey's first administration. See below n 69 and the reference there to Peter Adams Fatal Necessity, at ch 7. 


\section{MARTIN'S UNDERSTANDING OF THE TREATY OF WAITANGI}

Martin was an early observer of the way in which the Treaty of Waitangi was perceived by both Māori and Pakeha, and participated vigorously in debates that took place six years later on the significance of the Treaty in relation to native title. He was one of the few persons with legal training who had a facility in both Treaty languages. It is not clear at what point of time Martin acquired that facility but it had been acquired by 1847 when George Clarke described him as "a master of the Maori language". ${ }^{54}$ In addition he has become something of a sourcebook for Treaty historians and lawyers, but it is surprising that, given all of these credentials his views on the Treaty are not accorded greater weight in current debates.

George Barton, in his article, succinctly and accurately states Martin's view of the Treaty: ${ }^{55}$

For [Martin] the rock on which the relationship between the Maori people and the new settlers was based was the Treaty of Waitangi, a sacred compact which alone gave abiding justification for British legislation and administration and for the exercise of British sovereignty. Yet that philosophy was not reflected in his judicial attitudes towards the treaty: they rather reflected the prevailing view of parliamentary sovereignty and the royal prerogative which did not easily accommodate a treaty as a fundamental law.

There is only limited reference to the Treaty in Martin's judgments. It is referred to briefly in The Queen $v$ Symonds. ${ }^{56}$ This case concerned the validity of a purported sale by Māori directly to the plaintiff who relied on a certificate from Governor Fitzroy purporting to waive the Crown's right of pre-emption, but who could not rely on any grant from the Crown. Martin held that it was a well established principle of law that the Crown has the exclusive right to found a new colony and acquire new territory and that there is a customary title in the native occupiers that the Crown alone has the right to extinguish. ${ }^{57}$ This principle of law affecting colonies was not derived from the

54 George Clarke Pamphlet in answer to Mr James Busby's "On the Taranaki Question and the Treaty of Waitangi", above n 17, at 2.

55 GP Barton "Martin, William", above n 1.

56 The Queen (on the prosecution of CH McIntosh) v Symonds (1847) NZPCC 387 at 395-397. No mention of the Treaty was made in another case also involving the status of a purchase of land from Māori under the purported authority of a grant from Governor Fitzroy: $R v$ George Clarke SC Auckland, 24 June 1844 available at <www.vuw.ac.nz/law/nzlostcases>. The purchaser in this case was the missionary (and later Chief Protector of Aborigines, already referred to). This was the only judgment of Martin CJ (and Chapman J) to come before the Privy Council which reversed their judgments in The Queen $v$ Clarke (1851) NZPCC 516. The Privy Council held that the grant by Governor Fitzroy was made in breach of the legislative provision governing the exercise of the Governor's power.

57 David V Williams in his insightful A Simple Nullity? The Wi Parata case in New Zealand Law and History (Auckland University Press, Auckland, 2011) is with respect incorrect at 223-224 in treating, as being an erroneous innovation, the reference in Re the Lundon and Whitaker Claims Act 1871 (1872) 2 NZCA 41 at 
Treaty of Waitangi. The Court did not, therefore, need to decide the case under the Treaty and Martin observed that with the question as to the true meaning of the Treaty "as it stands in the native language" the Court had no concern. ${ }^{58}$ In particular the Court did not need to consider the meaning of the "exclusive right of pre-emption" in the English version of the Treaty. Martin was alive to the differences between the English and Māori versions of the Treaty and noted that those words do not appear in the Māori version. ${ }^{59}$

As George Barton observed, Martin took a high view of the Treaty regarding it as a sacred compact which alone gave binding moral justification for the exercise of British sovereignty. He

49 to the "common law of England" as providing the basis for native or aboriginal title. Chapman J at 390 of his judgment in Symonds after discussing the American cases states that the United States Supreme Court was "calling to its aid, throughout every portion of its judgment, the principles of the common law as applied and adopted from the earliest times by the colonial laws" and at 392 refers to the protection of native title in the cases that he cited from courts in the United States, as "recognizing the principles of the common law". Martin in his later writings (but while still in judicial office) refers on more than one occasion to the "common law" as being the basis for the principles on which native title in discovered or ceded territories was recognised and protected. In England and the New Zealanders (College Press, Auckland, 1847) at 26 he cites the passage from Chapman J's judgment that refers to "the principles of the common law as applied and adopted from the earliest times by Colonial Courts" and at 33 refers to "the common law of the British Colonies, by which lands within the Colonies are secured to their native owners". At 29 when summarising his view as to the three bases for asserting a native title Martin gives one of these as "the Common Law of the British Colonies". The fact that the Court in Re Lundon refers to the "common law of England" (emphasis added) is a distinction without a difference. Although the common law now flows in divergent streams, all of these streams have their origin in the common law of England. The court appears to be referring, as did Martin, to the principles of the common law as applied in colonial courts. There can be little doubt that Martin CJ and Chapman J were asserting a customary title on the part of native inhabitants that was derived from the common law as applied in colonial territories. What is of greater significance is that the Court applied this body of common law in order to hold that the plaintiff could not acquire a valid title directly from the native inhabitants notwithstanding the purported waiver of the Crown's right of preemption.

58 The Queen (on the prosecution of CH McIntosh) v Symonds, above n 56, at 397.

59 See above nn 57 and 58 and also below n 66. Ruth Ross in her seminal article on the Treaty "Te Tiriti o Waitangi Texts and Translations" (1972) 6 NZJH 129 at 144 discusses the meaning of the word "preemption" and the confusion that existed, particularly among Māori, as to the Crown's obligations under the Treaty: Governors Hobson and Fitzroy maintained that the Queen alone had the right to purchase and many Māori claimed that the Queen had only a first right of purchase and if the Crown did not purchase land that was offered, Māori were free to sell directly to third parties. Martin and Chapman JJ appear to have been aware of this dispute as Chapman J in his judgment in Symonds at 390-391 went out of his way to state that it was irrelevant what might be the "etymological" meaning or derivation of the word. It had a defined legal meaning from the earlier common law as applied in colonial territories and had not been used for the first time in the Treaty. Chapman J stated "The court must look at the legal import of the word, not its etymology" and regarded the Queen as having the sole right of purchase and the use of the word in the Treaty as necessarily carrying this meaning. Martin J at 397 raised the question but held that it was unnecessary for him to answer it as the plaintiff was purporting to rely on a waiver document that applied to him alone and not to any third party. 
referred to the colonisation of New Zealand as differing "from the mode pursued in many of the older colonies" with the "adoption of a more righteous and a wiser policy" 60 that, citing from the Attorney-General's argument recognised that "Power has duties as well as rights". His position was most clearly expressed in the pamphlet authored by him which was issued along with Bishop Selwyn as a protest against the wastelands legislation proposed in the mid-1840s by Earl Grey, Secretary of State for the Colonies at the Colonial Office. ${ }^{61}$ The publication, issued while Martin was holding office, attracted controversy notwithstanding Martin's efforts to limit its distribution to a few select persons. ${ }^{62}$

This is a remarkable document. Within a few years of the signing of the Treaty, it puts forward a powerful and tightly reasoned appeal for regarding the Treaty as providing the moral and legal basis for the transfer of sovereignty and the settlement of New Zealand. The arguments that Martin marshals, drawn from Colonial Office instructions and other preparatory documents, must still represent one of the ablest statements of the Treaty's central importance to New Zealand and has continuing relevance in the contemporary debates regarding the Treaty's significance and meaning. It is not possible in this article to do justice to the breadth and power of Martin's arguments in this publication. In very broad outline:

- Martin begins with the 1836 Select Committee report of the United Kingdom Parliament, promoted by the Aborigines Protection Society, which stated that "the Native Inhabitants have an incontrovertible right to their own soil - a sacred right which appears not to have been understood by this country".

- Points out that Lord Normanby's dispatch on the colonisation of New Zealand referred to this report and took up these same words when stating the "title [of the native inhabitants] to the soil and sovereignty of New Zealand is indisputable and has been solemnly recognised by the British Government".

60 The Queen (on the prosecution of CH McIntosh) v Symonds, above n 56, at 395.

61 William Martin England and the New Zealanders, above n 57.

62 The suggestion in Arthur Meek's dramatic production on the life of Mary Martin, On the Upside Down of the World that Martin was required to resign because of this incident appears to be without foundation. Henry Sewell who was in a position to know, attributes the resignation to Martin's ill health and his conscientious refusal to continue further in office until he had been granted a pension when his illness prevented him attending to the work of the court: Letter from Henry Sewell to EW Stafford (10 October 1857) in EW Stafford Stafford Papers (1846-1892) vol 2 cited in MW Hancock "Sir William Martin and the Maori people", above n 12. Martin's integrity was, however, rewarded as he was granted a pension for life by the New Zealand Parliament in 1858 and this enabled him to return to New Zealand. 
- Lord Normanby stated that although the Ministers of the Crown had gone too far in recognising New Zealand as a sovereign and independent state, ${ }^{63}$ "these are engagements which we formed and by which we must be bound".

- Reference is made to the instructions to Captain Hobson in 1839 under which the Queen disclaimed "every pretence to seize on these islands, or to govern them as a part of the dominions of Great Britain unless the free and intelligent consent of the natives expressed in accordance to their established usages be obtained".

- There is no claim by Hobson on the country by reason of sovereignty but on the basis of his instruction to obtain by fair and equal contracts with the natives, the cession to the Crown of their wastelands as may be progressively required for the occupation of settlers.

- $\quad$ The discussion with the Chiefs at the time of signing of the Treaty is referred to and the assurances given that their customs would be protected and their lands would not be seized against their will.

- $\quad$ Reference is made to various dispatches after the Treaty which confirmed the steps taken by Hobson to obtain cession from the natives, including Hobson's Dispatch of 9 December 1840 in which he stated:

They have been formally recognised by Great Britain as an Independent State; and even in assuming the dominion of the Country this principle was acknowledged, for it is on the deliberate act and cession of the Chiefs, on behalf of the people at large, that our title rests.

Further in a Dispatch to Hobson of 28 January 1841 it was confirmed that Her Majesty in the Royal Instructions "has distinctly established the principle that the territorial rights of the Natives as owners of the soil, must be recognised and respected.

On the basis of these and other supporting arguments Martin concluded: ${ }^{64}$

The title then of Great Britain to this country rests entirely upon a voluntary cession of Sovereignty of the country to the Queen. Therefore according to established principles of law, all private rights of property existing in the country at the time of cession remain unaffected.

This was so whether the land was occupied or unoccupied.

63 This was under the Declaration of Independence of 1835. Normanby had second thoughts as to whether this Declaration could constitute the Māori chiefs who signed it a sovereign State which could enter into a treaty.

64 Martin does not refer to Hobson's Proclamation of Sovereignty in the South Island and would no doubt have regarded this as an assertion of sovereignty as against foreign powers but, in view of the assurances given to Māori, not affecting their position under the Treaty. 
It was, therefore, axiomatic to him that the proposals now emanating from the Colonial Office for the Crown to take all unused lands ("wastelands" in the terminology of the day) was a serious breach of faith. He also expressed the view in the next section of his pamphlet that Earl Grey's instructions also involved a violation of established law. He concluded that there were three respects in which the instructions were unlawful: ${ }^{65}$

(1) by National Compacts and Assurances on the part of Britain [these have just been discussed];

(2) by the common law of the British colonies [as discussed in the Symonds case]; and

(3) by the constitutional rights of British subjects [the Treaty having guaranteed to Māori "all the rights and privileges of British subjects"].

Martin also has significant insights to offer in relation to the current debate on the differences between the Māori and English versions of the Treaty in relation to the cession of sovereignty and the meaning to be given in this respect to the Māori version. Martin, as mentioned earlier, had a facility in the Māori language and was familiar with the Māori version of the Treaty. He had no doubt, that given the background to the Treaty that he discussed in detail in England and the New Zealanders, sovereignty had been ceded to the Crown pursuant to the Treaty on the basis of the assurances that had been given to Māori in relation to their land. What, however, did Māori understand they were ceding?

The word used to translate 'sovereignty' was kawanatanga. It was a word described by historians as "missionary Māori" derived from the word for governor (kawana). Martin commented on this word in his paper on The Taranaki Question and gave his definition of what Māori would have understood by this word that they were ceding to the Crown. He stated: ${ }^{66}$

The rights which the natives recognised as belonging thenceforth to the Crown were such rights as were necessary for the Government of the Country and for the establishment of the new system. We called them "sovereignty"; the natives called them "kawanatanga" "Governorship". This unknown thing, the "Governorship", was in some degree defined by a reference to its object. The object was expressed "to avert the evil consequences which must result from the absence of Law". To the new and unknown Office they conceded such powers, to them unknown, as might be necessary for its due exercise.

This statement has been criticised by Ruth Ross for asserting that it was the New Zealanders who called this "unknown thing" kawanatanga. It was not Māori, but rather the missionaries who did so. That is, however, beside the point. What is of particular relevance is whether Martin was correct as to the way in which Māori at the time understood the word, whoever coined it. She does

65 William Martin England and the New Zealanders, above n 57, at 20.

66 William Martin "Further Papers relative to The Taranaki Question", above n 30, at 3. 
not address that question but instead has undertaken an excursion into what may have been a better translation, namely the use of the word mana. It is difficult to disagree with Martin as to what the word kawanatanga was meant to convey and how it was understood (which for him was the same thing). Martin transliterates the word to 'governorship' as Māori were familiar with the use of that word to describe Hobson's Australian counterpart, Governor Gipps and governors of other Australian territories, Norfolk Island and Tasmania and it was the word the Māori chiefs present used to address Hobson at the Treaty ceremony. They would then at least have understood the word to mean, as Martin indicated, the person or persons who had or were, in the case of Hobson, to have, responsibility for government which as a minimum covered responsibility for law and order and the ordering of "the new system" in other words of land dealing.

What Māori conceded to this Government was, as Martin said, the powers necessary for its due exercise. All other powers Māori retained to themselves. Again quoting Martin, "To themselves they retained what they understood full well [in comparison with the 'unknown thing' of governorship], the 'tino rangatiratanga' 'full chiefship', in respect of all their lands."67

This accords with the view expressed by Martin, cited earlier, that on the signing of the Treaty Māori were assured that their land and customs would be protected. He envisaged a period of transition during which Māori would progressively embrace a more law-ordered way of life. It was also the expectation of Māori that the ceding of sovereignty of this kind, would give to the Governor the power to bring in a law-based society and deal with the lawless elements that had been a feature of the country in the years prior to 1840. Martin as Chief Justice had an important part in that process. It was a view that Martin, on the evidence he had put forward, saw as shared by Hobson and the Colonial Office on the introduction of the Treaty and it was certainly the view of those missionaries who participated in the Treaty process. ${ }^{68}$ Martin's view, doubtless shared by Williams and most missionaries was expressed later in Confiscation of Native Lands: ${ }^{69}$

67 William Martin "Further Papers relative to the Taranaki Question", above n 30, at 3.

68 PD McKenzie "Public Christianity and Te Tiriti O Waitangi: How the Clapham Sect reached Down Under" (2010) 18(4) Stimulus at 25-29.

69 William Martin "Confiscation of Native Lands", above n 31, at 6. Martin also expresses this view in "The Taranaki Question", above n 30, at 31 referring to the attempt made in the Native Council Act to give Māori "the utmost possible share in the work of their own government", "incorporating this into our own system of civil institutions". See also Martin's statement in "Confiscation of Native Lands", above n 31, that apart from the criminal law "natives were to be left to their own usage". An illuminating discussion of the way in which successive colonial administrations approached law and custom is given by Peter Adams Fatal Necessity (Auckland University Press, Auckland, 1977) ch 7 and at 242-244 dealing with law and custom (although without any reference to Martin's writings). It is clear from that chapter that Martin sought to adhere to the view current at the time of the Treaty and of his appointment, but significant policy changes took place from 1847 under Governor Grey's first administration in relation to the extent to which Māori were to be involved in administering justice in those areas where what Martin called "chiefship" was being exercised. 
It is plain the framers of the treaty desired to bring all the natives of these islands into the position of subjects of the Crown; but it is not to be conceived that they contemplated at once among New Zealanders the minute and technical forms of English law; they regarded only the substance of the law; the substantial fruits of settled government; legal protection for life; legal protection for property. The power which accepts the position of a Sovereign and promises to regard certain men as its subjects, does not thereby undertake, at least, the duty of protecting the lives and properties of those men. This is a proposition, which I think no Englishman will question. This was our undertaking.

It follows that the allegations made by Ruth Ross and a number of later historians that there was deliberate or unconscious deception on the part of those who translated the Treaty, falls away. ${ }^{70}$ What they envisaged was a limited form of sovereignty which the word "kawanatanga" was apt to describe. The word "mana" used by Busby in translating the 1835 Declaration of Independence would have been inappropriate to describe what was being ceded in 1840. It appropriately described the full powers that the signing chiefs asserted against the rest of the world in 1835, the object of the Declaration being in part to warn off European powers from claiming any rights in what was asserted to be a sovereign territory. The word was quite inapt to describe the more limited powers that were being ceded in 1840. It is regrettable that little weight has been given to Martin's clear analysis of the situation. ${ }^{71}$

\section{A Simple Nullity?}

An interesting question is addressed by Prof DV Williams in his recent book, A Simple Nullity? Would Martin CJ have agreed with the decision in Wi Parata $v$ Bishop of Wellington? Williams is of the view that, "despite his modern reputation as a 'socially, liberal, humanitarian"', Martin would have agreed with Prendergast CJ and Richmond J in Wi Parata in holding that the Court could not entertain a claim asserting rights on the part of native landowners. ${ }^{72}$ Williams refers to Martin's

70 Ruth Ross "Te Tiriti o Waitangi Texts and Translations", above n 59, at 139-141. See also RJ Walker "The Treaty of Waitangi as a focus of Maori protest" in IH Kawharu (ed) Waitangi (Otago University Press, Auckland, 1989) at 263. This issue is discussed in some depth by Professor Alan Ward in his brief of evidence (Doc A19) before the Waitangi Tribunal Northland Inquiry (Wai 1040, 2010) at [28.3] and [32], particularly the discussion of limitations on sovereignty in [32.2] and [107]. The responses by Professor Ward to questions on the role of Henry Williams at 55-61 are also instructive.

71 Martin is speaking of the way in which those such as the Colonial Office, Hobson and Henry Williams and the Māori chiefs who signed the Treaty understood the word sovereignty in the Treaty. As Peter Adams Fatal Necessity, above n 69, at 190-209, has shown, the position on and understanding of sovereignty changed dramatically in the period following the Land Wars with the impact of the confiscations and largescale purchases of Māori land. It is a serious disservice to Henry Williams to attribute to him views on the nature of the sovereignty that was ceded under the Treaty which were not shared by the participants in 1840 and its immediate aftermath. A significant treatment of this issue is given by Dr Duncan Roper in a study nearing completion and expected to be published this year.

72 David V Williams A Simple Nullity? The Wi Parata case in New Zealand Law and History, above n 57, at 222. 
argument in his paper on Confiscation of Native Lands: "The case stands thus: no native can in any way enforce any right of ownership or occupation of land, held by the native tenure, in the courts of the Colony." 73

Martin's position was as George Barton described it. His views reflected the prevailing view of parliamentary sovereignty and the royal prerogative which did not easily accommodate the notion of the Treaty as a fundamental law. ${ }^{74}$ Dr Barton could have added that Martin, in step with judicial thinking at that time, did not regard native customary rights to land as being justiciable in the ordinary courts, at least as against the Crown. Williams is right in considering that Martin CJ would have been in agreement with the decision reached in Wi Parata. In that case the essential decision of the Court, as the Privy Council later stated, was a narrow one, namely that the Court had no jurisdiction to annul a Crown grant valid on the face of it, and that it followed that the native title had been extinguished by the Crown grant. The title so extinguished could not be reasserted on the ground that the donation underlying the Crown grant had failed. If Martin CJ had agreed with the court in Wi Parata that a Crown grant had in fact been issued (a matter of some controversy), then he would have agreed with the decision in that case.

Martin would, however, have been shocked by the pronouncements in that case that the Treaty was a simple nullity and would have agreed with the criticism made of the Wi Parata judgment in that respect by the Privy Council, ${ }^{75}$ and would on this point have agreed with the court in Mangakahia $v$ New Zealand Timber Co, where Gillies J referred to Wi Parata and the guarantee in art 2 of the Treaty and added "which is no such simple nullity". ${ }^{76}$

Martin would also have reacted to the statements in Wi Parata denying the existence of any body of Māori customary law and treating it as non-existent. He repeatedly referred to "native title" and the "rights" possessed by natives in their territorial lands. He regarded the body of customary usages in relation to Māori land as being akin to the separate system of Scots law in relation to land and the "diverse systems of law in our Indian possessions" recognising that "under the single sovereignty of the Queen of England there are many systems of law". ${ }^{77}$ Although he regarded sovereignty under the Treaty as bringing all the Queen's subjects under the one law, particularly the

73 William Martin "Confiscation of Native Lands", above n 31, at 7.

74 GP Barton "Martin, William", above n 1.

75 Nireaha Tamaki v Baker [1901] AC 561 (PC).

76 Mangakahia $v$ New Zealand Timber Co (1880) 2 NZSC 345. David Williams has drawn attention to this neglected judgment in A Simple Nullity? above n 57, at 230-231.

77 William Martin "Confiscation of Native Lands", above n 31, at 7. 
criminal law, he recognised that Māori would continue to be governed by their customary usages in relation to their lands and tribal organisation for example chieftainship, stating: ${ }^{78}$

The original theory appears to have been this, that bloodshed was to be suppressed to that extent, at any rate the criminal law was to be enforced; but that in other respects the natives were to be left to their own usage.

In addition, it is important to recognise that Martin's statements on the Treaty were made prior to 1862 when the Native Lands Act was enacted, a statute which in relevant respects was repeated in the Native Lands Act 1865 on which the Privy Council placed some weight. It is doubtful whether Martin would, at least from after the enactment of the Native Lands Act 1862, have agreed with the dicta in Wi Parata on the absence of any remedy on the part of Māori owners who sought to assert their right of occupation before the courts.

He was clearly of the view that Māori, as the original inhabitants had what he repeatedly called "rights" and "title" under the common law in relation to their land, and although he did not see these rights as justiciable under the Treaty, he took the view in Symonds that such rights arose independently of the Treaty to the extent that legislation on native land affirmed them. ${ }^{79} \mathrm{He}$ would, therefore, have agreed with the strong statements made by the Privy Council that following the enactment of the 1865 Act it was "too late in the day" to be asserting that there was no customary law of which the courts could take cognisance and he would have considered, in line with the Privy Council, that the Supreme Court could pursuant to that Act inquire into title or some interest in native land and make provision for investigation of such titles or interests and remit to a Court, specially constituted for that purpose, the ascertainment of those interests.

Martin could also properly have come to the view that the Mangakahia case (where the Court held that an estate according to native custom could not support an action in trespass where the claimant was not in actual possession) was wrongly decided and is inconsistent with the express statement of the Privy Council in Nireaha Tamaki v Baker: ${ }^{80}$

If the appellant (the Maori owners) can succeed in proving that he and the members of his tribe are in possession and occupation of the lands in dispute under a Native title which has not been lawfully extinguished, he can maintain this action to restrain an unauthorised invasion of his title

The "possession and occupation" to which the Privy Council refers is not the narrow physical possession referred to in Mangakahia but the claim to ownership through native custom and usages which the Privy Council (at 379) equates with "the Native title of possession and occupancy" and

78 Ibid.

79 The Queen (on the prosecution of CH McIntosh) v Symonds, above n 56, at 394 and 397-398.

80 Nireaha Tamaki v Baker, above n 75, at 383. 
"his own title of occupancy and possession" and contrasts this with the "radical title of the Crown", where such title has not been extinguished. With respect, it is difficult to see how, in the face of the statements made by the Privy Council, the argument put forward by Professor DV Williams can be sustained, that (until the innovations introduced into the law by more recent cases since 1986), no action could be maintained to support any title or interest in Māori customary land.

\section{MARTIN'S UNDERSTANDING OF MĀORI LAND TENURE}

The view which Martin held on the nature of native land tenure has already been touched on when discussing his views on the Treaty. They are most fully expressed in the opening section of his paper on The Taranaki Question. Martin demonstrates a careful and detailed appreciation of Māori practices and his views on land tenure were treated with respect in the Native Land Court during the subsequent period. In very general terms Martin recognised: ${ }^{81}$

(a) Prior to European settlement transfer of land was uncommon but land was at times transferred from one tribe to another as payment for assistance in war or to cover losses in war or as compensation to end a war on fair terms.

(b) Land occupied by the community belonged to the whole community. Although land could be cultivated individually the community had a reversionary right to all the land. Martin was careful to refer to "the community" as tenure could be held by sub-tribes, hapū or smaller family groups.

(c) The chief is expected to defend and protect the rights of his people and so could have a significant say in matters of land disposal. To make a sale of land thoroughly regular both the chief and people should consent.

(d) Generally there is no such thing as an individual claim, clear and independent of the community right.

(e) The Treaty reserved to Māori all then existing rights of property. It did not enlarge or restrict such rights but left them as they were. It recognised the existence of chiefs and dealt with them as such.

(f) Although ceding kawanatanga (the power to govern) to the Queen, Māori retained full chiefship over their lands including the right of sale or disposal.

(g) The Crown alone could purchase land from Māori and no one could obtain an individual title to land except by way of grant from the Crown.

Martin's views on land tenure were the subject of strong attack when he expressed them in support of Wiremu Kingi's position in the Taranaki conflict. CW Richmond (who later formed part

81 William Martin, "The Taranaki Question", above n 30, at 1-2. 
of the court in Wi Parata and Professor Williams shows is likely to have written the judgment), Busby and others disputed his views and a vigorous pamphlet war followed. ${ }^{82}$ Martin was defended by George Clarke, former Chief Protector of Aborigines, who endorsed Martin's views on every point. ${ }^{83}$ Those who opposed Martin had, in comparison with him, a limited and partial view of Māori land dealings. Unfortunately, however, the controversy left its mark and Lennard in his generally careful and well researched biography has repeated the allegation that on the Taranaki question "Martin's views may not have been of the soundest". ${ }^{84}$ Yet this view is scarcely consistent with Lennard's statement earlier in the paragraph that "on matters of native custom his opinions have been treated with the utmost respect by later judges both in the Supreme Court and the Native Land Court". ${ }^{85}$

\section{CONFISCATIONS}

Following the principal battle engagements in the Waikato, the colonial legislature determined to proceed with legislation for the confiscation of Māori land. Martin had from the start deplored the way in which the country had moved into war. He was alarmed at the prospect of a colonial legislature in which Māori had no representation taking it on itself to confiscate large areas of land in Taranaki and Waikato. On 16 November 1863, Martin wrote a lengthy memorandum addressed to William Fox, then Native Minister in the New Zealand Government which he requested be brought to the attention of the Colonial Secretary in London.

Martin's memorandum is again a masterly piece of sustained argument. He began by outlining the circumstances in which land may be forfeited and questioned the validity of the Colonial Government's action. Forfeiture following conquest in war (which in substance was what the government was seeking to achieve) could only be undertaken against foreign enemies. As Martin pointed out later in his memorandum, Māori were British subjects not foreigners. The other ground possibly available to the Government against its own subjects was forfeiture by way of special

82 Those whose views were aligned with Martin were labelled traitors and JC Richmond stated "Martin must be sadly wanting in depth to have acted and thought as he has done". Letter from JC Richmond to Mary Richmond (27 January 1861) in GH Scholefield (ed) The Richmond-Atkinson Papers (Government Printing Office, Wellington, 1960) vol 1.

83 George Clarke, above n 17. Martin himself replied and reiterated and clarified his views on native land tenure in Remarks on Notes Published for the New Zealand Government 1861 (WH Dalton, London, 1861) reprinted Kessinger Publishing Co, La Vergne, 2010.

84 Guy Lennard Sir William Martin: the life of the first Chief Justice of New Zealand, above n 19, at 51. Unfortunately this comment was repeated uncritically in Robin Cooke (ed), above n 24, at 39. Harold Miller gives a different assessment, stating that Martin's The Taranaki Question is "perhaps the ablest piece of polemical writing ever produced in New Zealand": Harold Miller Race Conflict in New Zealand 1814-1865 (Blackwood and Janet Paul, Auckland, 1966) at 230.

85 Martin's views on Māori land tenure in relation to the Taranaki controversy have been treated with the same respect by the Waitangi Tribunal: Waitangi Tribunal The Taranaki Report (Wai 143, 1996). 
legislative enactment. Martin pointed out that such legislation was enacted only for reasons of public defence or for some national purpose and then only upon appropriate terms of compensation to private owners. The circumstances in which the Colonial Parliament was proposing to act did not fit these criteria and it was, in Martin's view, using legislation for a novel and unjustified purpose against the Crown's own subjects and in doing so was acting without discrimination affecting those who had never resisted along with those who had. Martin examined in some detail the events that had precipitated resistance and explained why in his view that resistance did not justify forfeiture.

In a salutary passage he referred to the example of Ireland and stated: ${ }^{86}$

The example of Ireland may satisfy us how little is be effected towards the quieting of a country by the confiscation of private land; how the claim of the dispossessed owner is remembered from generation to generation, and how the brooding sense of wrong breaks out from time to time in fresh disturbance and crime.

We can feel some sense of gratitude that this prophecy has not been fulfilled in the case of New Zealand when regard is had to the generally peaceful response of those Māori who were dispossessed at the time.

The Memorandum reiterates Martin's concern, throughout his period of office and in subsequent years, that the rule of law be established firmly in the new country. He referred to the "great progress" that had been made during the initial years until 1853 and quoted from an unnamed minister who had stated that by that time "the Maori tribes were perfectly peaceful throughout the colony". ${ }^{87}$ More recently James Belich has echoed this view and in his social study of the period expresses the view that despite sporadic tensions and frictions at the interface between the settler areas and the Māori interior the two communities got on surprisingly well. "Between 1847 and 1860 there was not only peace but also a degree of cooperation between Maori and Pakeha spheres, in economics in particular." 88

The War set all this progress back and much that Martin had worked for was lost. Martin stated that he recognised that matters had moved to the point where "the folly of Waikato must be checked and crime be punished" but he urged that in achieving this purpose government should act with humanity "neither vindictively nor selfishly but as becomes a great, generous and Christian

86 William Martin "Confiscation of Native Lands", above n 31, at 14, specifically at [13].

87 Ibid at 6 .

88 James Belich Making Peoples, above n 28, at 229. An illuminating discussion of the way in which successive colonial administrations approached law and custom is given by Peter Adams Fatal Necessity, above n 69, at ch 7 of his text dealing with law and custom. It is apparent from that chapter that Martin stated in his writings and seeks to adhere to the view current at the time of the Treaty and of his appointment but significant policy changes took place from 1847 under Governor Grey's first administration. 
nation." ${ }^{89}$ Above all he concluded that government, particularly now that it had such a large part in native affairs must act in accordance with law: ${ }^{90}$

A Government in which the assembly has so large a part, should be from the nature of the case a Government by law; yet proclamations have been made wholly unwarranted by law. The Executive Government has claimed to exercise powers which neither the law of England or the colony has conferred on it. Let us regard them as military and extraordinary measures, and let us for the future see that in an adherence to the law of England is our only strength and safety. The Crown can act on no rule but that which is furnished by the law... and nothing could be more unreasonable or unseemly than that we, while seeking to bring the native people to accept our system, should ourselves be departing from it, violating the very law of which we are the professed upholders and champions. In fact, if we do not hold fast to this principle, there remains no limit to the extent of extravagance to which in the present excitement, the minds of men may be carried, so as to forget not the mere form of law, but even those fundamental principles of fairness and equity which lie at the foundation of our English law, and of our whole English system.

These wise words were not heeded in 1863 and 1864 and, in the differing circumstances that we face in our generation, we neglect them to our peril today.

89 William Martin "Confiscation of Native Lands", above n 31, at 13.

90 Ibid at 15. 